\title{
ОСОБЛИВОСТІ ОРГАНІЗАЦІЙНО-ПРАВОВОГО ЗАБЕЗПЕЧЕННЯ ВИКОНАННЯ ВИРОКІВ ЩОДО НЕПОВНОЛІТНІХ ОСІБ
}

Ільїна О. В.

\section{ВСТУП}

Кримінальне переслідування, пов'язане із застосуванням легального примусу з боку держави, - це один із найбільш дієвих, але водночас і один із найбільш складних засобів підтримання правопорядку в державі. Застосування кримінального покарання призводить до суттєвої зміни способу життя особи, її діяльності й участі в суспільних процесах. Складність застосування кримінального покарання пов'язана із тим, що воно має бути персональним, виконувати одночасно превентивну, правоохоронну та виховну функцію, а також відповідати характеру злочинного діяння, тобто бути співставним.

Саме тому застосування кримінального покарання, а також виконання вироків суду щодо неповнолітніх осіб $є$ одним із найбільш складних елементів кримінально-правового захисту суспільних відносин. Неповнолітні особи мають специфічне кримінально-правове становище, зумовлене їхнім віком, рівнем індивідуальної правової свідомості, а також рівнем психологічної стійкості та правової культури. Все це має визначальний вплив на формування особистості, а також на ставлення неповнолітньої особи до скоєного злочинного діяння. Тому основним завданням кримінальної відповідальності стає не лише покарання, але й виправлення модусу поведінки неповнолітньої особи. 3 цих позицій пошук особливостей організаційно-правового забезпечення виконання вироків щодо неповнолітніх осіб пов'язаний із теоретико-методологічним забезпеченням можливих шляхів підвищення ефективності та дієвості виконання вироків. Для держави важливим є формування генофонду нації, основним потенціалом чого і виступає молодь. Відтак виконання вироків щодо неповнолітніх осіб не повинно створювати в них відчуття асоціалізації, викреслення державою їх із нормального суспільного життя.

Додатково слід зазначити, що через контекст пошуку ефективних, однозначних і змістовних, навіть вичерпних способів викладення нормативно-правового закріплення механізму виконання вироків суду щодо неповнолітніх осіб підвищуватиметься якість виконання функцій держави стосовно забезпечення належного рівня прав осіб, навіть 
у процесі виконання вироків щодо них. Сучасна вітчизняна пенітенціарна система об'єктивно характеризується низьким рівнем дотримання вимог законодавства у сфері виконання вироків через брак фінансування, недостатній рівень компетенції працівників системи виконання покарань тощо. Держава повинна забезпечувати належний рівень організаційно-правового забезпечення процесу виконання вироків, особливо щодо неповнолітніх осіб. Через це пошук особливостей такого забезпечення, який робитиметься в межах цього дослідження, повинен супроводжуватися виділенням найбільш слабких місць практичного виконання вироків стосовно вказаного кола осіб.

Тобто низька ефективність пенітенціарної системи та спроможність реагувати на особливості правового становища неповнолітніх осіб працівників такої системи - це додаткова обставина, на яку необхідно звернути увагу, щонайменше на рівні теоретичного доктринального забезпечення механізмів виконання вироків. Держава повинна гарантувати, що всі стадії кримінального процесу, в т. ч. i процес виконання вироків, відбуватимуться із дотриманням прав і свобод людини і громадянина в межах, які не суперечать самому кримінальному покаранню.

Про актуальність обраної теми також свідчать статистичні дані щодо кількості злочинів, вчинених неповнолітніми. Так, у 2017 р. кількість кримінальних проваджень щодо неповнолітніх збільшилася. Зокрема, протягом року у судах першої інстанції перебувало на розгляді 6408 кримінальних проваджень стосовно 7976 неповнолітніх осіб. Із них розглянуто 3872 , у т. ч.: 1) із постановленням обвинувального вироку - 2854 провадження щодо 3462 осіб (iз них на підставі угоди про примирення - 237 проваджень, а про визнання винуватості - 89); 2) із закриттям провадження у справі стосовно 545 осіб; 3 ) із застосуванням примусових заходів медичного характеру - 15 проваджень щодо 16 осіб, 4) повернуто прокурору 90 обвинувальних актів щодо 128 осіб. Виправдано 19 неповнолітніх, що на 7 осіб більше порівняно з показниками 2016 р. На кінець 2017 р. в судах першої інстанції перебувало 2536 нерозглянутих кримінальних проваджень ${ }^{1}$. Наведена статистика $є$ невтішною та свідчить про високий рівень злочинності серед неповнолітніх. Останне, у свою чергу, тягне за собою певні особливості організаційно-правового забезпечення виконання вироків щодо неповнолітніх осіб.

\footnotetext{
1 Злочини неповнолітніх: про що говорить статистика? URL: https:/sud.ua/ru/news/ blog/117843-zlochini-nepovnolitnikh-pro-scho-govorit-statistika (дата звернення 22.11.2019).
} 
Ці особливості пов’язані з тим, що в цьому віці остаточно формується характер особи, ії вольові властивості, психіка $є$ найбільш уразливою і тому потребує забезпечення особливого утримання (наприклад, окремо від повнолітніх осіб, котрі вчинили особливо тяжкий злочин, проведення виховної роботи).

Також на підтвердження актуальності обраної теми свідчать міжнародні договори, якими визначено правове забезпечення виконання вироків щодо неповнолітніх осіб та інші особливості здійснення провадження стосовно цієї категорії осіб. Йдеться про згадану вище Конвенцію про права дитини, Керівні принципи Комітету Міністрів Ради Європи щодо судочинства, дружнього до дитини, Мінімальні стандартні правила ООН, які стосуються відправлення правосуддя щодо неповнолітніх («Пекінські правила»), затверджені Генеральною Асамблеєю ООН (Пекін, 29 листопада 1985 р.), Правила ООН щодо захисту неповнолітніх, позбавлених волі (1990р.), Керівні принципи ООН запобігання злочинності серед неповнолітніх (Ер-Ріядські керівні принципи 1990 р.) тощо.

\section{1. Сучасний стан законодавчого забезпечення виконання вироків щодо неповнолітніх осіб}

Становлення організаційно-правового забезпечення виконання вироків щодо неповнолітніх осіб пройшло свій історичний розвиток. Так, «на західноукраїнських землях, починаючи з кінця XVIII ст., реалізовувалася кримінально-виконавча політика Австрійської імпеpiї» ${ }^{2}$. Неповнолітні, які утримувалися в окремих відділеннях у кримінальних тюрмах, удень перебували у спільних камерах, а на ніч роз'єднувалися шляхом особливого одиночного облаштування спальних місць. У тюрмах засуджені розділялися на три категорії, кожна 3 яких утримувалася окремо. До відділу А поміщалися засуджені «із зіпсованими моральними якостями, котрі становили небезпеку для інших; до відділу В - рецидивісти; до відділу С - неповнолітні й ті, хто відбував покарання вперше»³. Також неповнолітнім могло бути призначено відбування покарання у виправних домах. Зокрема, «вони були призначені для неповнолітніх злочинців (яким не виповнилося 18 років), котрі могли б отримати у них релігійне й моральне

\footnotetext{
2 Кримінально-виконавче право України : підручник. Т. I (у 2 т.) / Музика А.А., Конопельський В.Я., Письменський Є.О та ін. ; за заг. ред. С.Ю. Бараша. Київ : Нац. акад. внутр. справ, ФОП Кандиба Т.П. 2018. С. 79.
}

3 Австрийские тюрьмы гражданского ведомства. Тюремный вестник. 1898. № 3. С. 122. 
виховання, а також здобути фах. Утримання у виправному домі мало тривати доти, доки не досягалася мета покарання - виправлення, але не довше, ніж до досягнення особою 20 років» ${ }^{4}$. Наведені положення свідчать про те, що із проходженням етапів становлення кримінально-виконавчої системи розвивалася і система виконання покарань щодо неповнолітніх осіб.

Дослідивши історичний аспект зазначеної проблематики, звернемо увагу на порівняльно-правовий. Для прикладу, характерною рисою пенітенціарної системи Японії є розвинена диференціація позбавлення волі, заснована на класифікації засуджених. Особи, що є засудженими, передаються до певних центрів і вже потім на основі ряду послідовних дій і результатів цих дій можуть бути направлені в установи для: осіб із незначними злочинними нахилами; осіб із більш розвиненими злочинними нахилами; іноземних громадян; осіб, термін покарання яких перевищує 8 років; осіб, молодших 20 років; психічно неповноцінних осіб; осіб із різними захворюваннями і фізичними вадами ${ }^{5}$. Варто додати, що диференційований підхід до виконання покарання $\epsilon$ одним із засобів забезпечення особистої безпеки засуджених в установах виконання покарань.

Повертаючись до національного кримінально-виконавчого законодавства, слід відзначити, що в Україні також застосовується диференційований підхід в організаційно-правовому забезпеченні виконання вироків щодо неповнолітніх осіб. Це має історичні передумови, про які зазначалося вище. Також про окремий диференційований підхід в організаційно-правовому забезпеченні виконання вироків щодо неповнолітніх осіб свідчить той факт, що серед міжнародних нормативно-правових актів у сфері виконання покарань і поводження із засудженими науковці виділяють нормативно-правові акти стосовно окремих категорій правопорушників або певних професійних груп із персоналу установ та органів виконання покарань, міжнародні стандарти, зокрема ті, які стосуються неповнолітніх ${ }^{6}$. Необхідно розуміти,

4 Шуп’яна М. Система додаткових покарань за австрійським кримінальним законодавством другої половини ХІХ ст. Вісник Львівського університету. Серія «Юридична». 2014. Вип. 59. С. 166-168.

5 Порядок та умови інших кримінальних покарань. Виникнення буржуазної тюремної системи. Кримінально-виконавче право зарубіжних країн. URL: http://studopedia. ru/3_189957_ugolovno-ispolnitelnoe-tyuremnoe-ilipenitentsiarnoe-pravo-zarubezhnih-stran-sshafrg-frantsiya-angliya-yaponiya-idr.html (дата звернення: 20.11.2019).

6 Кримінально-виконавче право України: підручник. Т. I (у 2 т.) / Музика А.А., Конопельський В.Я., Письменський Є.О та ін. ; за заг. Є.Ю. Бараша. Київ : Нац. акад. внутр. справ, ФОП Кандиба Т.П. 2018. С. 128. 
що вік злочинця виступає додатковим аспектом під час вибору виду кримінальної відповідальності, а у випадку із неповнолітніми особами слід враховувати, що вік особи виконує ще й функцію обмеження застосування певних видів покарання.

Це не диференціація у контексті вибірковості покарання, а спосіб розширення можливостей для неповнолітніх осіб ресоціалізуватися повною мірою після відбуття покарання. Йдеться про можливість виправлення без надмірного тиску системи кримінального примусу з боку держави на психіку молодої особи, котра найчастіше навіть не усвідомлює тяжкість наслідків, спричинених її злочинними діями. 3 іншого боку, обмеження можливостей для застосування низки видів кримінальної відповідальності до неповнолітніх повинно було б дати змогу законодавцю застосовувати й особливий вид покарання, який можливий лише щодо неповнолітньої особи, наприклад, примусове навчання у закладах закритого типу із підвищеним рівнем дисципліни. Прикладом цього можуть слугувати військові ліцеї, де відбувається одночасне навчання, виховання та формування правової свідомості й культури неповнолітньої особи.

Щодо законодавчого закріплення організаційно-правового забезпечення виконання вироків стосовно неповнолітніх осіб слід вказати на такі положення:

1) Глава 21 Кримінально-виконавчого кодексу України (далі КВК України), яка має назву «Особливості відбування покарання у виді позбавлення волі засудженими жінками і неповнолітніми», закріплює заходи заохочення (ст. 144) та заходи стягнення, що застосовуються до засуджених неповнолітніх (ст. 145), посадових осіб, які застосовують заходи заохочення і стягнення до засуджених неповнолітніх, та обсяг їхніх повноважень (ст. 146), залишення у виховних колоніях засуджених, котрі досягли вісімнадцятирічного віку (ст. 148), участь громадськості у виправленні та ресоціалізації засуджених неповнолітніх (ст. 149) та інші положення ${ }^{7}$;

2) згідно з КВК України серед органів і установ виконання покарань окремо виділені арештні доми, які виконують покарання у виді арешту, та виховні колонії, що виконують покарання у виді позбавлення волі на певний строк стосовно засуджених неповнолітніх (ст. 19) ${ }^{8}$. В арештних домах тримаються повнолітні особи, а також неповнолітні, яким

\footnotetext{
7 Кримінально-виконавчий кодекс України. Відомості Верховної Ради Украӥни. 2004. № 3-4. Ст. 21.

8 Там само.
} 
на момент постановлення вироку виповнилося 16 років і які засуджені за злочини невеликої тяжкості (ст. 15 КВК України $)^{9}$;

3) громадські роботи виконуються неповнолітніми не більш як 2 години на день, але не менше 25 годин на місяць (ч. 2 ст. 38 КВК України);

4) засуджені до покарання у виді арешту неповнолітні тримаються в умовах ізоляції від інших засуджених (ч. 1 ст. 51 КВК України);

5) неповнолітні засуджені мають право на короткострокові побачення без обмеження їх кількості (ч. 3 ст. 51 КВК України);

6) у виправних i виховних колоніях встановлюється роздільне тримання: чоловіків i жінок, неповнолітніх і дорослих (ч. 1 ст. 92 КВК України) та інші положення ${ }^{10}$.

Аналіз національного кримінально-виконавчого законодавства дає підстави стверджувати, що описаний вище диференційований підхід певним чином визначає організаційно-правове забезпечення виконання вироків щодо неповнолітніх осіб. Тобто, на наш погляд, забезпечення диференційованого підходу до неповнолітніх осіб у системі виконання покарань і є належним організаційно-правовим забезпеченням виконання вироків щодо неповнолітніх осіб.

Звужуючи сферу дослідження до аналізу організаційно-правового забезпечення виконання вироків щодо неповнолітніх осіб, вважаємо за необхідне виділити такі положення.

По-перше, неповнолітні особи тримаються окремо від інших засуджених в установах виконання покарань. Це стосується вимоги щодо окремого тримання неповнолітніх під час відбування покарання у вигляді арешту від чоловіків, жінок, засуджених, які раніше притягалися до кримінальної відповідальності, засуджених, котрі раніше відбували покарання в місцях позбавлення волі, і засуджених, які раніше працювали в суді, органах прокуратури, юстиції та правоохоронних органах. Названа вимога є вимогою імперативного характеру і жодних винятків не передбачає. Для прикладу наведено аналогічне положення щодо тримання іноземних громадян і осіб без громадянства. Згідно 3 ч. 1 ст. 51 КВК України іноземні громадяни й особи без громадянства зазвичай тримаються окремо від інших засуджених. Ключове слово, на яке ми звернули увагу, - «зазвичай», тобто імперативної вимоги закон щодо іноземних громадян або осіб без громадянства не містить ${ }^{11}$.

\footnotetext{
9 Кримінально-виконавчий кодекс України. Відомості Верховної Ради Украӥни. 2004. № 3-4. Ст. 21.

10 Там само.

11 Там само.
} 
Додамо, що закріплення в національному кримінально-виконавчому законодавстві правила про тримання неповнолітніх правопорушників окремо від дорослих відповідає міжнародним стандартам у цій сфері, зокрема закріпленим у Мінімальних стандартних правилах поводження 3 в'язнями ${ }^{12}$.

Так само неповнолітні тримаються окремо від дорослих під час виконання покарання у виді позбавлення волі (ч. 1 ст. 92 КВК України). За сумлінну поведінку і ставлення до праці та навчання, активну участь у роботі самодіяльних організацій і виховних заходах до засуджених неповнолітніх можуть застосовуватися заходи заохочення. Для прикладу, це надання права відвідування культурно-видовищних і спортивних заходів за межами виховної колонії в супроводі працівників колонії та ін. (ст. 144 КВК України) $)^{13}$.

По-друге, для неповнолітніх осіб законодавцем встановлено додаткові привілеї, спрямовані на задоволення потреб неповнолітніх громадян, які пов'язані з особливостями віку, а саме фізичними й емоційними потребами. Про це свідчать норми кримінально-виконавчого законодавства щодо надання права засудженому до арешту неповнолітньому одержувати короткострокові побачення без обмеження їх кількості. У порівняльно-правовому аспекті зазначимо, що інші засуджені до арешту мають право одержувати один раз на місяць короткострокове побачення (ч. 3 ст. 51 КВК України). Також варто вказати на те, що неповнолітні засуджені мають привілеї й у наданні часу для прогулянок - 2 години. У свою чергу, інші засуджені - 1 годину (ч. 5 ст. 51 КВК України) $)^{14}$.

На нашу думку, до процесуальних привілеїв, передбачених для неповнолітніх, також слід віднести те, що «до засуджених неповнолітніх і жінок гамівна сорочка не застосовується. Забороняється застосовувати заходи фізичного впливу, спеціальні засоби і зброю до жінок із явними ознаками вагітності, осіб похилого віку або з вираженими ознаками інвалідності та неповнолітніх, крім випадків вчинення ними групового або збройного нападу, збройного опору» (ч. 3 ст. 106 КВК України) $)^{15}$. Такі привілеї пов'язані насамперед із

12 Мінімальні стандартні правила поводження з в'язнями. URL: https://zakon.rada.gov.ua/ laws/main/995_212 (дата звернення: 23.11.2019).

13 Кримінально-виконавчий кодекс України. Відомості Верховної Ради України. 2004. № 3-4. Ст. 21

14 Там само.

15 Там само. 
розширеним колом потреб неповнолітніх осіб. За звичайних умов суспільних відносин поза межами системи виконання покарання їх статус охороняється державою. Вони мають певне коло виключних прав, так само як і коло виключних обмежень, пов'язаних із віком. У системі ж виконання покарання держава намагається дотримуватися особливого високого рівня забезпечення фізичних і духовних потреб неповнолітніх осіб. Це і проявляється у наданні їм розширеного кола можливостей щодо проведення вільного часу під час відбування покарання у вигляді обмеження чи позбавлення волі, а також у недопущенні застосування до неповнолітніх осіб «звичайного» для працівників пенітенціарних органів набору заходів примусу. Проблема застосування фізичного впливу, надмірного фізичного впливу на засуджених повинна нарешті зайняти відповідне місце в науковому дискурсі щодо пошуку напрямів підвищення ефективності та дієвості системи відбування покарань.

Фізичний та інший вплив на неповнолітніх осіб деформує їхню психіку, створює неправильне ставлення до правової реальності, заміщає категорії «службова особа» категоріями «державний апарат», «держава», «суспільство». Все це формує такий спосіб мислення в неповнолітньої особи, відповідно до якого вона почувається ворожим, небажаним, маргінальним елементом для суспільства, соціуму. Таке почуття зводить нанівець спроби ресоціалізації, призводить до того, що кримінальне покарання не виконує функцію виховання, превентивну чи правоохоронну, а в розумінні неповнолітніх виступає лише засобом протидії йому особисто з боку держави. Тому існують обмеження фізичного впливу, застосування спеціальних засобів, а також інших дій щодо цих осіб із боку працівників пенітенціарних закладів.

По-третє, під час виконання вироків у вигляді громадських і виправних робіт неповнолітнім гарантуються особливі трудові права та соціальні гарантії, зокрема щодо часу роботи (не більш як 2 години на день відповідно до ч. 2 ст. 38 КВК України) у разі відбування покарання у вигляді громадських робіт. Для виправних робіт враховуються особливості використання праці неповнолітніх осіб й організації процесу праці за КЗпП України. Такий підхід законодавця не є преференцією, а повинен розглядатися як окрема гарантія щодо захисту прав засуджених неповнолітніх осіб. «Незважаючи на назву, за своєю суттю виправні роботи є ближчими до штрафу, ніж до громадських робіт, i фактично не передбачають прямого «виправного» елемента. Виправні роботи можуть бути застосовані лише до тих неповнолітніх, які 
перебувають у трудових відносинах (уклали трудову угоду), вік неповнолітнього не може бути меншим 16 років» ${ }^{16}$. Таким чином, застосування до неповнолітніх осіб вироків у вигляді громадських і виправних робіт пов'язане не лише із положеннями КВК України, але і з положеннями КЗпП, що робить організаційно-правове забезпечення їх виконання особливим, оскільки воно перебуває на перетині положень кримінально-виконавчого та трудового права.

По-четверте, до неповнолітніх як до особливої верстви населення застосовуються засоби реабілітації та ресоціалізації. Перш ніж розкрити вказане положення, слід пояснити, що «ідея ресоціалізації засуджених виникла у 80-х рр. XX ст. і втілилася у створенні принципово нової моделі організації покарань, яка отримала назву «реінтеграційна ${ }^{17}$. Вітчизняне кримінально-виконавче законодавство передбачає норму-роз'яснення терміна «ресоціалізація» - свідоме відновлення засудженого в соціальному статусі повноправного члена суспільства; повернення його до самостійного загальноприйнятого соціально-нормативного життя в суспільстві (ч. 2 ст. 6 КВК України) $)^{18}$.

\section{2. Ресоціалізація та пробація як елемент організаційно-правового забезпечення виконання вироків щодо неповнолітніх осіб}

Науковці доходять висновку, що основними завданнями виконання покарання у виді позбавлення волі неповнолітніх $є$ виправлення, ресоціалізація, перевиховання засуджених, загальна та спеціальна превенція ${ }^{19}$. Зрозуміло, що ресоціалізація має відбуватися щодо кожного засудженого, який став на шлях виправлення. Однак, на наше переконання, ресоціалізаційні заходи мають застосуватися з особливим підходом до неповнолітніх, оскільки своєчасне вжиття таких заходів впливає на все майбутнє життя молодих людей, котрі опинилися у конфлікті із законом і потребують допомоги.

\footnotetext{
16 Щепоткіна В.В., Слуцька Т.І. Особливості здійснення кримінальних проваджень щодо неповнолітніх. Київ : Вищий спеціалізований суд України з розгляду цивільних і кримінальних справ, Національна школа суддів України. 2017. С. 117.

17 Яцишин Ю.М. Сучасний вітчизняний і міжнародний інноваційний досвід ресоціалізації неповнолітніх засуджених. Міжнародний науковий вісник: збірник наукових статей за матеріалами XXVII Міжнародної науково-практичної конференції (Ужгород - Будапешт, 26-29 листопада 2013 р.) /ред. кол. В.І. Смоланка, І.В. Артьомов та ін. Ужгород: ДВНЗ «УжНУ», 2014. Вип. 8 (27). С. 354.

18 Кримінально-виконавчий кодекс України. Відомості Верховної Ради Украӥни. 2004. № 3-4. Ст. 21.

19 Стаднік В.В. Виконання покарання у виді позбавлення волі щодо неповнолітніх : автореф. дис. ... канд. юрид. наук : 12.00.08. Львів, 2018. С. 10.
} 
Так, у Мінімальних стандартних правилах Організації Об'єднаних Націй, які стосуються відправлення правосуддя щодо неповнолітніх («Пекінські правила»), вказано, що «слід приділяти достатню увагу здійсненню позитивних заходів, які передбачають повну мобілізацію всіх можливих ресурсів, включаючи сім'ю, добровольців та інші групи суспільства, а також школи та інші громадські інститути, з метою сприяння благополуччю підлітка, аби скоротити необхідність втручання з боку закону, й ефективного, справедливого і гуманного поводження 3 підлітком, що перебуває у конфлікті з законом» (п. 1.3.) $)^{20}$.

Щодо реалізації засад ресоціалізації в українських реаліях, то слід вказати на виховну роботу, яка проводиться із засудженими до обмеження волі. Так, «з особами, котрі відбувають покарання у виді обмеження волі, адміністрацією виправного центру, а також власником підприємства, установи, організації або уповноваженим ним органом, де працюють засуджені, та громадськими організаціями проводиться соціально-виховна робота. Активна участь засуджених у виховних заходах заохочується і враховується при визначенні ступеня їхнього виправлення» (ст. 65 КВК України) ${ }^{21}$.

Із приводу соціального призначення виховних колоній вчені зазначають, що «найважливішими завданнями виховних колоній, як i виправних, $є$ належне виконання вироку суду і застосування засобів виправлення та ресоціалізації, основними з-поміж яких, згідно 3 чинним законодавством, є встановлений порядок виконання та відбування покарання (режим), пробація, суспільно корисна праця, соціально-виховна робота, загальноосвітне і професійно-технічне навчання, громадський вплив. Чинником, що відрізняє виховні колонії від виправних, є пріоритет виховної роботи та навчання вихованців. Водночас у їх діяльності й досі доволі сильно виражена каральна функція, яка розкривається в умовах тримання неповнолітніх. Виховні колонії мають ті самі недоліки, що і кримінально-виконавчі установи. Це зазвичай пояснюється «дорослою» спрямованістю правового регулювання діяльності виховних колоній» ${ }^{22}$. Повністю погоджуємося iз автором, адже здебільшого у місцях позбавлення волі діяльність

\footnotetext{
20 Мінімальні стандартні правила Організації Об’єднаних Націй, що стосуються відправлення правосуддя щодо неповнолітніх («Пекінські правила») URL: https://zakon.rada.gov.ua/ laws/main/995_211 (дата звернення: 23.11.2019)

21 Кримінально-виконавчий кодекс України. Відомості Верховної Ради Украӥни. 2004. № 3-4. Ст. 21

22 Стаднік В.В. Виконання покарання у виді позбавлення волі щодо неповнолітніх : автореф. дис. ... канд. юрид. наук : 12.00.08. Львів, 2018. С. 8.
} 
уповноважених осіб спрямована на виправлення засуджених дорослих осіб. Особливих виправних програм до неповнолітніх осіб майже не застосовується. Однак повинні бути певні відмінності, які мають проявлятися у застосуванні основних засобів виправлення і ресоціалізації, що має виражені виховні та педагогічні аспекти. Проблематика полягає в тому, що форми і методи роботи чітко не регламентовані відомчим законодавством. Колектив вихователів має право самостійно обирати форми, методики та прийоми провадження виховної роботи залежно від особливостей організації діяльності колонії, іiі розташування, пори року, етнонаціональних особливостей, особливостей категорії засуджених тощо 23 . Звісно, тут постає проблема людського фактору та ставлення до своїх професійних обов'язків.

Науковці зазначають, що «дуже важливою у виховному процесі $\epsilon$ чітка взаємодія вчителів школи, вихователів загонів і відділень, викладачів професійного училища, майстрів виробництва. Саме цим забезпечується принцип єдності педагогічних вимог. Однак робота в цьому напрямі $\epsilon$ творчою і вимагає створення єдиного навчально-виховного комплексу, який охопить спільною метою всі служби колонії». Щодо вимог до сучасних працівників із неповнолітніми, засудженими до покарання в літературі зазначається, що «для сучасних виховних колоній потрібні висококваліфіковані фахівці, які знають вікову специфіку роботи з неповнолітніми злочинцями. Це, насамперед, соціальні педагоги, котрі можуть кваліфіковано визначити ступінь моральної деформації засуджених і розробити відповідні інноваційні заходи» ${ }^{24}$. Вважаємо, що задля належного виконання своїх обов'язків для працівників із неповнолітніми мають бути запроваджені спеціальні курси із підвищення кваліфікації та проведення відбіркових іспитів перед допуском до роботи із неповнолітніми.

Надзвичайно важливим елементом ресоціалізації, виховання та відновлення деформованих кримінально караним діянням модусів поведінки неповнолітньої особи, на нашу думку, виступає Звіт про неповнолітнього обвинуваченого у кримінальному провадженні щодо неповнолітніх. На виконання т. зв. Токійських правил 1990 р.

23 Стаднік В.В. Виконання покарання у виді позбавлення волі щодо неповнолітніх : автореф. дис. ... канд. юрид. наук : 12.00.08. Львів, 2018. С. 10.

24 Яцишин Ю.М. Сучасний вітчизняний і міжнародний інноваційний досвід ресоціалізації неповнолітніх засуджених. Міжнародний науковий вісник: збірник наукових статей за матеріалами XXVII Міжнародної науково-практичної конференції (Ужгород - Будапешт, 26-29 листопада 2013 р.) / ред. кол. В.І. Смоланка, І.В. Артьомов та ін. Ужгород: ДВНЗ «УжНУ», 2014. Вип. 8 (27). С. 356. 
(Мінімальних стандартних правил ООН щодо заходів, не пов'язаних із тюремним ув'язненням) і Пекінських правил 1985 р. (Мінімальних стандартних правил ООН щодо відправлення правосуддя стосовно неповнолітніх) вітчизняна судова система внаслідок аналізу, узагальнення та виправлення помилок сучасної вітчизняної практики застосування заходів кримінально-правового характеру щодо неповнолітніх осіб розробила певні рекомендації, які містять важливі аспекти виконання вироків щодо таких осіб.

У своєму Листі «Про деякі питання здійснення кримінального провадження щодо неповнолітніх» від 18 липня 2013 р. № 223-1134/0/4-13 Вищий спеціалізований суд України з розгляду цивільних і кримінальних справ зазначає: «Індивідуалізація покарання є важливою вимогою принципового характеру, що передбачає персоніфікацію кримінальної відповідальності: вона настає лише щодо конкретної особи, яка вчинила злочин (ст. 2, 18, 50 КК України). Тому призначення покарання з урахуванням ступеня тяжкості вчиненого злочину, особи неповнолітнього й обставин, що пом'якшують чи обтяжують покарання, повинно максимально сприяти досягненню мети покарання, яка полягає у виправленні неповнолітнього засудженого, його вихованні та соціальній реабілітації» $)^{25}$. Цим же Листом Вищий спеціалізований суд України з розгляду цивільних і кримінальних справ затверджує форму Звіту, «з урахуванням якого суд у кримінальному провадженні щодо неповнолітнього зможе винести рішення, що відповідатиме найкращим інтересам неповнолітнього ${ }^{26}$. Тобто самі судові органи, розуміючи проблему ресоціалізації та виховання неповнолітніх навіть у процесі відбування ними покарання, потребують додаткової інформації щодо кожної такої особи і саме так реалізують персоналізацію кримінальної відповідальності.

Більше того, у Листі «Про практику здійснення судами кримінального провадження щодо неповнолітніх» від 16 січня 2017 р. № 223-66/0/4-17 Вищий спеціалізований суд України з розгляду цивільних і кримінальних справ зазначає: «Перед ухваленням вироку суду необхідно обов'язково розглянути питання щодо наявності підстав для застосування до неповнолітнього обвинуваченого примусових заходів виховного характеру. У разі обвинувачення неповнолітнього

25 Про деякі питання здійснення кримінального провадження щодо неповнолітніх : Лист Вищого спеціалізованого суду від 18 липня 2013 р. № 223-1134/0/4-13. URL: https://zakon.rada.gov.ua/laws/show/v1134740-13.

26 Там само. 
у скоєнні вперше кримінального проступку, злочину невеликої тяжкості або необережного злочину середньої тяжкості правильним вбачається застосовувати за наявності визначених законом умов, незважаючи на відсутність відповідного клопотання прокурора, діючи в порядку, передбаченому ч. 1 ст. 97 КК та ч. 3 ст. 497 КПК України, примусові заходи виховного характеру, звільнивши неповнолітнього від кримінальної відповідальності» ${ }^{27}$. Таким чином, суди не лише намагаються застосовувати ті обмеження й умови при розгляді кримінальних справ щодо неповнолітніх осіб, які закріплені у кримінальному та кримінально-процесуальному законодавстві, але й створюють власні акти рекомендаційного характеру, якими розширюють можливості для ресоціалізації та виховання неповнолітніх осіб. Причому примусове виховання розглядається як один із засобів державного примусу, легітимізуючи одночасно виховну функцію кримінальної відповідальності та систему додаткових гарантій недопущення порушення права неповнолітніх осіб.

Все це демонструє важливий правовий зв'язок між особливим конституційно-правовим статусом неповнолітньої особи, котра має розширене коло прав, зменшене коло обов'язків і додаткові гарантії з боку держави щодо всебічного розвитку таких осіб. Кримінальне, кримінально-процесуальне та кримінально-виконавче законодавство, яке розроблялося на підставі та з урахуванням конституційних гарантій і конституційних обмежень, лише втілює все це у сфері застосування до таких осіб системи легального державного примусу за вчинення ними кримінально караного діяння. Цінність вказаного нами правового зв'язку полягає у тому, що за його допомогою у сфері виконання покарання права неповнолітніх осіб забезпечуються максимальним чином, навіть з урахуванням вимог кримінально-виконавчого законодавства, але забезпечення таких прав має на меті продовження розвитку неповнолітньої особи навіть під час відбування нею покарання, що повинно усвідомлюватися як спосіб тиску держави у разі порушення законності та встановленого правопорядку, що відбувається деперсоніфіковано і застосовується до всіх злочинців. У випадку ж із неповнолітньою особою держава лише створює необхідну систему додаткових заходів і засобів забезпечення реалізації прав неповнолітньої особи, і це повинно розглядатися як гуманізація покарання та його відбування.

27 Про практику здійснення судами кримінального провадження щодо неповнолітніх : Лист Вищого спеціалізованого суд України з розгляду цивільних і кримінальних справ від 16 січня 2017 p. № 223-66/0/4-17. URL: https://ips.ligazakon.net/document/VRR00215. 
Окремо слід зауважити, що до неповнолітніх застосуються особливі пробаційні заходи. У Законі України «Про пробацію» визначено: «Пробація щодо неповнолітніх - це пробація стосовно осіб віком від 14 до 18 років. Пробація здійснюється з урахуванням вікових і психологічних особливостей неповнолітніх (ч. 1 ст. 12)» ${ }^{28}$. Названий закон не містить винятків щодо застосування видів пробації. Можна стверджувати, що до неповнолітніх осіб можуть застосовуватися всі види пробації: досудова; наглядова; пенітенціарна пробація (ст. 8).

Щодо особливостей застосування пробації щодо неповнолітніх осіб слід вказати на такі положення:

- пробація щодо неповнолітніх здійснюється органом пробації спільно з органами і службами у справах дітей, спеціальними установами та закладами, які здійснюють їх соціальний захист і профілактику правопорушень (ч. 4 ст. 12);

- орган пробації сприяє залученню засуджених неповнолітніх до навчання та здобуття ними повної загальної середньої освіти (ч. 5 ст. 12);

- соціально-виховна робота із засудженими неповнолітніми може проводитися із залученням батьків або їхніх законних представників (ч. 6 ст. 12$)^{29}$.

Система пробації є тим комплексом заходів, спрямованих на ресоціалізацію неповнолітніх осіб, їх виховання та формування необхідного рівня індивідуальної свідомості, який має перетворити їх на повноцінних членів суспільства. Пробація, до якої залучаються спеціалізовані установи та відповідні професіонали у сфері психологічного виховання, психологічного відновлення тощо, покликана забезпечити не тільки відновлення деформованої психіки особи внаслідок вчинення кримінально караного діяння та відбування покарання за нього, але і формування додаткових спеціальних навичок. Ці навички є необхідними, оскільки неповнолітні особи під час відбування покарання, особливо у вигляді обмеження чи позбавлення волі, вибувають із процесу навчання у загальноосвітніх закладів.

\section{ВИСНОВКИ}

Організаційно-правове забезпечення виконання вироків щодо неповнолітніх осіб передбачає існування певних гарантій забезпечення прав і законних інтересів неповнолітніх осіб під час виконання

\footnotetext{
28 Про пробацію : Закон України від 05 лютого 2015 р. № 160-VIII. Відомості Верховної Ради. 2015. № 13. Ст. 93.

29 Там само. 
вироків, зокрема використання диференційованого підходу під час виконання покарань щодо неповнолітніх осіб. Такий підхід у системі виконання покарань $є$ належним організаційно-правовим забезпеченням виконання вироків щодо неповнолітніх осіб, до якого належать такі положення: неповнолітні особи тримаються окремо від інших засуджених в установах виконання покарань; для неповнолітніх осіб законодавцем встановлено додаткові привілеї, спрямовані на задоволення потреб неповнолітніх громадян, які пов'язані з особливостями віку, а саме фізичними й емоційними потребами, зокрема надання права засудженому до арешту неповнолітньому одержувати короткострокові побачення без обмеження їх кількості; надання часу для прогулянок 2 години; встановлення заборони застосовувати заходи фізичного впливу, спеціальні засоби і зброю, крім випадків вчинення ними групового або збройного нападу, який загрожує життю і здоров'ю персоналу колонії чи інших осіб, або збройного опору; до неповнолітніх застосовуються засоби реабілітації та ресоціалізації; до неповнолітніх застосуються особливі пробаційні заходи.

Доведено, що під час відбування покарання неповнолітні особи користуються певними державними гарантіями, пов'язаними із їхніми віковими обмеженнями щодо виконання низки функцій, зокрема під час реалізації функції праці. Крім того, до неповнолітніх осіб застосовується система державних гарантій і захисту від несанкціонованого застосування заходів фізичного впливу під час виконання вироків, пов'язаних із обмеженням чи позбавленням волі. Це пов'язано із тим, що кримінальна відповідальність має на меті не лише усунення і примусове переривання державою кримінально караних діянь і відновлення системи правопорядку, але й виховання та запобігання надалі кримінально караним діянням. Виховання неповнолітніх осіб відіграє важливе значення, хоча й може виступати додатковим елементом державного легального примусу. Такі заходи $є$ безальтернативними, оскільки ці особи вибувають зі звичайного для них соціуму.

3 наведеного вище робимо висновок, що розвиток організаційно-правового забезпечення виконання вироків стосовно неповнолітніх осіб повинен відбуватися з урахуванням особливостей суспільної свідомості, правової культури та психологічного стану неповнолітніх осіб. Ресоціалізація таких осіб - це спосіб насамперед формування, а не відновлення модусу поведінки, яка укладається в допустимі державою межі. Тому вона напряму пов'язана із системою пробації, де з неповнолітніми особами працюють відповідні фахівці, котрі допомагають ство- 
рити правильне сприйняття правової реальності та недопущення правової деформації індивідуальної свідомості неповнолітніх осіб.

\section{АНОТАЦІЯ}

У статті проаналізовано організаційно-правове забезпечення виконання вироків щодо неповнолітніх осіб. Встановлено, що законодавство передбачає певні гарантії забезпечення прав і законних інтересів неповнолітніх осіб під час виконання вироків, зокрема використання диференційованого підходу під час виконання покарань щодо неповнолітніх осіб, що є належним організаційно-правовим забезпеченням виконання вироків стосовно цієї категорії осіб, до якого належать такі положення: по-перше, неповнолітні особи тримаються окремо від інших засуджених в установах виконання покарань. Це стосується вимоги щодо окремого тримання неповнолітніх під час відбування покарання у вигляді арешту від чоловіків, жінок, засуджених, які раніше притягалися до кримінальної відповідальності, засуджених, котрі раніше відбували покарання в місцях позбавлення волі, і засуджених, які раніше працювали в суді, органах прокуратури, юстиції та правоохоронних органах; по-друге, для неповнолітніх осіб законодавцем встановлено додаткові привілеї, спрямовані на задоволення потреб неповнолітніх громадян, що пов'язані з особливостями віку, а саме фізичними й емоційними потребами; по-третє, до неповнолітніх як до особливої верстви населення застосовуються засоби реабілітації та ресоціалізації. Тут йдеться про те, що найважливішими завданнями виховних колоній, як і виправних, є належне виконання вироку суду і застосування засобів виправлення та ресоціалізації, основними з яких за чинним законодавством $\epsilon$ встановлений порядок виконання та відбування покарання (режим), пробація, суспільно корисна праця, соціально-виховна робота, загальноосвітнє і професійно-технічне навчання, громадський вплив. Чинником, що відрізняє виховні колонії від виправних, $є$ пріоритет виховної роботи та навчання вихованців; по-четверте, до неповнолітніх застосуються особливі пробаційні заходи з урахуванням вікових і психологічних особливостей неповнолітніх.

\section{ЛІТЕРАТУРА}

1. Конституція України. Відомості Верховної Ради України. 1996. № 30. Ст. 141.

2. Конвенція про права дитини. Зібрання чинних міжнародних договорів Украӥни. 1990. № 1. С. 205. 
3. Злочини неповнолітніх: про що говорить статистика? URL: https://sud.ua/ru/news/blog/117843-zlochini-nepovnolitnikh-pro-scho-govoritstatistika (дата звернення 22.11.2019).

4. Кримінально-виконавче право України: підручник: Т. I (у 2 т.) / Музика А.А., Конопельський В.Я., Письменський Є.О та ін. ; за заг. ред. С.Ю. Бараша. Київ : Нац. акад. внутр. справ, ФОП Кандиба Т.П. 2018. 364 c.

5. Австрийские тюрьмы гражданского ведомства. Тюремный вестник. 1898. № 3. С. 100-123.

6. Шуп'яна М. Система додаткових покарань за австрійським кримінальним законодавством другої половини XIX ст. Вісник Львівського університету. Серія «Юридична». 2014. Вип. 59. С. 166-168.

7. Порядок та умови інших кримінальних покарань. Виникнення буржуазної тюремної системи. Кримінально-виконавче право зарубіжних країн. URL: http://studopedia.ru/3_189957_ugolovno-ispolnitelnoetyuremnoe-ilipenitentsiarnoe-pravo-zarubezhnih-stran-ssha-frg-frantsiyaangliya-yaponiya-idr.html (дата звернення 20.11.2019).

8. Кримінально-виконавчий кодекс України. Відомості Верховної Ради України. 2004. № 3-4. Ст. 21.

9. Мінімальні стандартні правила поводження 3 в'язнями. URL: https://zakon.rada.gov.ua/laws/main/995_212 (дата звернення 23.11.2019).

10. Яцишин Ю.М. Сучасний вітчизняний і міжнародний інноваційний досвід ресоціалізації неповнолітніх засуджених. Міжнародний науковий вісник : збірник наукових статей за матеріалами XXVII Міжнародної науково-практичної конференції (Ужгород - Будапешт, 26-29 листопада 2013 р.) / ред. кол. В.І. Смоланка, І.В. Артьомов та ін. Ужгород: ДВНЗ «УжНУ», 2014. Вип. 8 (27). С. 352-357.

11. Стаднік В.В. Виконання покарання у виді позбавлення волі щодо неповнолітніх : автореф. дис. ... канд. юрид. наук : 12.00.08. Львів, 2018. 23 c.

12. Мінімальні стандартні правила Організації Об'єднаних Націй, що стосуються відправлення правосуддя щодо неповнолітніх («Пекінські правила») URL: https://zakon.rada.gov.ua/laws/main/995_211 (дата звернення: 23.11.2019).

13. Про пробацію : Закон України від 05 лютого 2015 р. № 160-VIII. Відомості Верховної Ради. 2015. № 13. Ст. 93.

14. Щепоткіна В.В., Слуцька Т.І. Особливості здійснення кримінальних проваджень щодо неповнолітніх. Київ : Вищий спеціалізований суд України з розгляду цивільних і кримінальних справ, Національна школа суддів України. 2017. 238 с. 
15. Про практику здійснення судами кримінального провадження щодо неповнолітніх : Лист Вищого спеціалізованого суд України з розгляду цивільних і кримінальних справ від 16 січня 2017 р. № 223-66/0/4-17. URL: https://ips.ligazakon.net/document/VRR00215.

16. Про деякі питання здійснення кримінального провадження щодо неповнолітніх : Лист Вищого спеціалізованого суду від 18 липня 2013 р. № 223-1134/0/4-13. URL: https://zakon.rada.gov.ua/laws/show/v1134740-13.

\section{Information about author:}

Ilina O. V.,

Candidate of Law Sciences, Associate Professor of the Department of Criminal Law and Criminology of the Faculty of Law

Taras Shevchenko National University of Kyiv 60, Vladimirskaya str., Kyiv, Ukraine

DOI https://doi.org/10.30525/978-9934-588-43-3/2.5 